\title{
Salmonella enteritidis' vaccine produces in vitro and in vivo protection against colonization
}

\begin{abstract}
Salmonella enteric can be considered as one of the most important causes of food-poisoning with poultry thought to be the main source. Although S. Typhimurium, S. Enteritidis and the vast majority of other Salmonella serovars generally produce little systemic disease in adult chickens, they are able to colonize the alimentary tract of poultry. The two caeca are the main sites of the colonization of Salmonellae in chickens, and the bacteria can be easily harvested from the caeca for analysis. Bacterial proteins analyses utilizing SDS-PAGE showed differences between in vitro and in vivo that out of about 40 protein bands of in vitro preparation only a few (3-5) bands can be visualized from in vivo preparations. We suggested that some avian proteases might be responsible. Accordingly, and to investigate the hypothesis that an inactivated vaccine harvested from chickens is thought to be more protective than bacteria grown in broth culture, the immunogenicity of inactivated vaccines, either proteins or formalin killed bacteria (S. Enteritidis) harvested from chicken intestine and those from broth culture (in vitro), were compared using bacterial proteins or formalin killed bacteria as an orally in ${ }^{\circ}$ Culated vaccine candidate in chicken. The results demonstrated that sonicated proteins extracts in general have a stronger effect as vaccines against $S$. Enteritidis colonization in chickens than formalin killed bacteria. In contrast, the in vitro sonicated proteins obtained from a nutrient broth culture had a much better protective vaccine effect than the in vivo sonicated proteins preparations harvested from bacteria grown in chickens.
\end{abstract}

Volume 4 Issue 3 - 2017

\author{
Altayeb Elazomi,' Mahasin EA Rahman,' \\ Dhawi A, ${ }^{2}$ Susan Liddell, ${ }^{3}$ Margret Lovell, ${ }^{3}$ \\ Paul Barrow ${ }^{3}$ \\ 'Faculty of Medical Technology, University of Zawia, Libya \\ ${ }^{2}$ Faculty of Veterinary Medicine, University of Tripoli, Libya \\ ${ }^{3}$ University of Nottingham, UK
}

Correspondence: Altayeb Elazomi, Faculty of Medical Technology, University of Zawia, Libya, Emailelazomi@yahoo.com

Received: February 20, 2016 | Published: March 17, 2017

\section{Introduction}

Many bacterial pathogens such as Clostridium, Staphyl ${ }^{\circ} \mathrm{C}^{\circ} \mathrm{Ccus}$, Campylobacter and many other bacterial strains are capable of causing food-poisoning, and Salmonella enterica can be considered as one of the most important causes with poultry thought to be the main source. Although S. Typhimurium, S. Enteritidis and the vast majority of other Salmonella serovars generally produce little systemic disease in adult chickens, they are able to colonize the alimentary tract of poultry, resulting in contamination of poultry carcasses and entry into the human food chain. However, there is a great demand to control food-poisoning salmonellosis at both breeder and layer levels at the national and global level in order to produce Salmonelle-free poultry products, due to the current correlation between $S$. Enteritidis PT4 and poultry products. Salmonellosis costs the European Union a minimum of 500-900 million Euros annually. Salmonellosis in food animals is a major target for reduction of human infection by the European Union. Legislation has been introduced to monitor the most important Salmonellae serovars. The major Salmonellae serovars of public health consequence are S. Typhimurium and $S$. Enteritidis (causing 15\% and 60\% respectively of all cases in Europe in 2002).

Elazomi and Dhawi studied newly-hatched chickens infected with $S$. Enteritidis. They analyzed proteins of $S$. Enteritidis in the caeca of 1-day old checks (in vivo) together with a comparison with nutrient broth medium (in vitro) in order to detect changes in the pattern of protein expression during infection. The preliminary exploratory study of individual bands identified major proteins (flagellin of $S$. Enteritidis and Typhimurium $f(i C)$ and mixtures of proteins including $60 \mathrm{kDa}$ chaperonin groEL and glyceraldehyde-3-phosphate dehydrogenase gap $A$. Some proteins may be expressed equally both in vivo and in vitro (e.g. fimbrial, flagellar, outer membrane protein, metabolic , regulatory, and LPS-synthesis encoded genes). These proteins are predicted to play a major role in colonization. Chicken caecal colonization by paratyphoid Salmonella (e.g.
Enteritidis, Typhimurium and others) has been linked to the physical attachment by fimbriae ${ }^{1}$ motility, ${ }^{2}$ type three secretion system (T3SS) of Salmonella Pathogenicity Islands "SPI-1 and SPI-2", ${ }^{3}$ bacterial cell wall component lip polysaccharide "LPS" 4,5 and outer membrane proteins "OMPs". ${ }^{6}$ This comparison showed differences between the two profiles and indicated that it is difficult to make a reasonable comparison as out of about 40 protein bands of in vitro preparation only a few (3-5) bands can be visualized from in vivo preparations, the reason behind that thought to be the degradation of in vivo protein with some avian proteases.

Then we hypothesized that inactivated vaccines prepared from bacteria grown in vivo in chickens will give better protection than a vaccine prepared from bacteria cultured in vitro because they will be expressing antigens normally expressed during infection/ colonisation. Accordingly, and to investigate the hypothesis that an inactivated vaccine harvested from chickens is thought to be more protective than bacteria grown in broth culture, the immunogenicity of inactivated vaccines, either proteins or formalin killed bacteria $(S$. Enteritidis) harvested from chicken intestine and those from broth culture (in vitro), were compared using bacterial proteins or formalin killed bacteria as an orally in ${ }^{\circ} \mathrm{Culated}$ vaccine candidate in chicken.

\section{Materials and methods}

\section{Preparation of formalin-killed bacterin from bacterial}

\section{Cells cultured in vitro in nutrient broth}

A single colony of $S$. Enteritidis PT4 (antibiotic sensitive parent strain) was in ${ }^{\circ}$ Culated into $10 \mathrm{ml} \mathrm{NB}$ and incubated overnight at 37 ${ }^{\circ} \mathrm{C}$ and $1 \mathrm{ml}$ of this broth culture was transferred into $2 \mathrm{x} 100 \mathrm{ml} \mathrm{NB}$ in $250 \mathrm{ml}$ flasks and incubated for two hours at $37^{\circ} \mathrm{C}$ in a shaking incubator at $200 \mathrm{rpm}$. Each flask was then decanted to three $50 \mathrm{ml}$ Falcon tubes each containing $33.3 \mathrm{ml}$, the tubes then centrifuged at $5000 \mathrm{~g}$ for $30 \mathrm{~min}$ at $20^{\circ} \mathrm{C}$ and the supernatants were discarded 
without disturbing the pellets. Subsequently the pellet from each tube was re-suspended with $3.33 \mathrm{ml} \mathrm{NB}$, then the content of three Falcon tubes arising from the same flask were mixed into one Falcon tube. The contents $(10 \mathrm{ml} \mathrm{NB} 109$ bacterium $/ \mathrm{ml})$ which is equivalent to $108 / 0.1 \mathrm{ml}=3 \times 108$ bacterium $/ 0.3 \mathrm{ml}=5 \times 108 / 0.05 \mathrm{ml}$ which used for chicken injection (i.m) to both breast sides.

\section{Preparation of formalin-killed bacterin from bacterial}

\section{Cells cultured in vivo in chicken caeca}

90 newly hatched chickens were in $^{\circ}$ Culated orally with $S$. Enteritidis PT4 (antibiotic-sensitive parent strain) culture (1x106 cell). On the following day the chickens were killed and the infected caecal contents were collected. Caecal contents from three of the chickens were collected separately for viable count estimations and purity checking. Caecal contents from the remaining birds were collected together in two Falcon tubes in dry ice (1 tube each day as the collection was made over two separate days (from 15 and 40 birds respectively) and used for this vaccine preparation. The first tube that contained the caecal contents of 15 birds contained $0.936 \mathrm{~g}$ and $2.5 \times 1010 \mathrm{cfu} / \mathrm{ml}$ and tube two that contained the caecal contents of 40 birds contained $4.652 \mathrm{~g}$ and $1 \times 1011 \mathrm{cfu} / \mathrm{ml}$; so the total weight was $5.5 \mathrm{gm}$ in $5.5 \mathrm{ml}$. Therefore, the total bacterial number was $1.25 \times 1011$ bacteria. Both tubes were diluted together in $12.5 \mathrm{ml}$ PBS and mixed well and $3 \mathrm{ml}$ were collected from them and added to $27 \mathrm{ml}$ of NB for formalization. Each sample was diluted to thus contain $1 \times 109 \mathrm{cfu} / \mathrm{ml}$ and was stored at $-80^{\circ} \mathrm{C}$ until used.

\section{Formalization of $S$. Enteritidis killed vaccine}

To each bottle of $10 \mathrm{ml}$ suspension of bacteria $0.2 \mathrm{ml}$ of $40 \%$ formaldehyde was added and vortexed for 30 s and divided equally between $10 \times 1 \mathrm{ml}$ sterile tubes (Eppendorff) and stored in a cold room at $4{ }^{\circ} \mathrm{C}$ until needed.

\section{Preparation of sonicated protein vaccine}

Whole cell proteins were prepared from S. Enteritidis bacteria harvested from chickens or from a NB culture.

\section{Preparation of in vivo S. Enteritidis protein vaccine}

A total of 100 newly hatched chickens were in ${ }^{\circ} \mathrm{Culated}$ orally within $18 \mathrm{~h}$ of hatching. Chickens were infected orally with $0.1 \mathrm{ml}$ of a culture of the antibiotic-sensitive parent $S$. Enteritidis PT4, grown for $16 \mathrm{~h}$ in nutrient broth at $37^{\circ} \mathrm{C}$ and diluted in sterile nutrient broth to contain $107 \mathrm{cfu} / \mathrm{ml}$. After $16-18 \mathrm{hs}$ post-infection chickens were killed one-by-one, and the caecal contents were harvested from both chicken caeca of each bird. The caecal contents of three randomly chosen chicks were transferred to three separate sterile universal tubes which were placed on ice to test for purity and viable bacterial number estimation on MacConkey agar and nutrient agar. The caecal contents of the remaining chickens were put in $50 \mathrm{ml}$ Falcon tubes in dry ice and then were stored at $-80^{\circ} \mathrm{C}$ until needed. Three chicks were left without in ${ }^{\circ}$ Culation and their uninfected caecal contents were used to streak on MacConkey agar and nutrient agar plates and incubated for overnight at $37^{\circ} \mathrm{C}$ to ensure that there were no contaminants with other bacteria. For the vaccine preparations the $S$. Enteritidis-infected caecal contents were diluted in nutrient broth and then centrifuged at $20,000 \times \mathrm{xg}$ for $5 \mathrm{~min}$ at $4^{\circ} \mathrm{C}$ (Avanti ${ }^{\circledR} \mathrm{J}-\mathrm{E}$ Beckman centrifuge coulter), then the supernatant was discarded and the pellets were resuspended in NB, followed by sonication (Sonics VCX500) for 5 min immediately after adding the protease inhibitors (Sigma P8465). This sonicates was then centrifuged at $15,000 \mathrm{~g}$ for $10 \mathrm{~min}$ at $4^{\circ} \mathrm{C}$. Subsequently, the supernatant was filtered using $0.45 \mu \mathrm{m}$ filters and stored in $1 \mathrm{ml}$ aliquots in Eppendorff tubes at $-20^{\circ} \mathrm{C}$ until required.

\section{Preparation of in vitro $S$. Enteritidis protein vaccine}

A single colony of the parental $S$. Enteritidis PT4 sensitive strain was picked and used to in ${ }^{\circ} \mathrm{Culate} 10 \mathrm{ml} \mathrm{NB}$ in a universal bottle which was then incubated overnight at $37^{\circ} \mathrm{C}$. On the following day $250 \mathrm{ml}$ flasks, each containing $100 \mathrm{ml}$ nutrient broth, were in ${ }^{\circ} \mathrm{Culated}$ with $1 \mathrm{ml}$ of the overnight broth culture of $S$. Enteritidis PT4 and incubated overnight at $37^{\circ} \mathrm{C}$ shaking incubator $(150 \mathrm{rpm})$. The contents of these broth cultures were divided into four $50 \mathrm{ml}$ centrifuge tubes and centrifuged at $20,000 \mathrm{x} \mathrm{g}$ for $5 \mathrm{~min}$ at $4^{\circ} \mathrm{C}$ (Avanti ${ }^{\circledR} \mathrm{J}-\mathrm{E}$ Beckman centrifuge coulter). The pellet from each tube was resuspended in $5 \mathrm{ml} \mathrm{NB}$ and sonicated for $5 \mathrm{~min}$ (Sonics VCX500)) after adding the protease inhibitors (Sigma P8465), followed by centrifugation at $15,000 \mathrm{xg}$ for $10 \mathrm{~min}$ at $4^{\circ} \mathrm{C}$ and filtration as mentioned above. The proteins preparations were then stored at $-20^{\circ} \mathrm{C}$ until required.

\section{Vaccine Quality Control}

Protein sonicates harvested from both in vivo and in vitro environment were streaked on MacConkey and nutrient agar plates which were incubated overnight at $37^{\circ} \mathrm{C}$ to chick for any Salmonella growth, this also applied for the formalized bacteria.

\section{First vaccination experiment}

A lot of 100 1-day commercial layer chickens obtained from Millennium Hatchery Hy-Line UK Ltd (Studley Warwickshire), were utilized in this experiment. On the day of arrival birds were divided into five groups each of 20 birds with each group being placed in separate rooms which were cleaned down with a mixture of water and disinfectant (Trigene Disinfectant 20L Clear from Scientific Laboratory Supplies Ltd (CLE1320). Followed by chemical fogging with Virkon disinfectant from Sigma (Z692158), this allowed to rest for more than $24 \mathrm{~h}$ and rinsed off. Chicks were distributed between the rooms as follows (in vivo formalin-killed - Room I; in vivo sonicated proteins - Room II; in vitro formalin-killed - Room III; in vitro sonicated protein - Room IV; unimmunized - Room V). All chickens were kept on solid flooring covered with wood straw and were provided with food and sterile drinking water. Subsequently, all birds in all groups were in ${ }^{\circ}$ Culated with $0.1 \mathrm{ml}$ of neat Avigard gut microflora (Microbial Developments Limited, UK), then at the fifth day of age all chickens were in ${ }^{\circ} \mathrm{Culated}$ intramuscularly $(\mathrm{i} / \mathrm{m})$, into the breast muscle, with $0.05 \mathrm{ml}$ containing either formalin-killed bacterial cells or protein preparation. Chickens were also in ${ }^{\circ} \mathrm{Culated}$ orally with $0.1 \mathrm{ml}$ of the corresponding vaccine for each group as shown in Table 1. The remaining group number five (control) was in ${ }^{\circ}$ Culated with sterile NB. At three weeks of age the vaccination program was repeated with all birds in ${ }^{\circ} \mathrm{Culated}$ with $0.3 \mathrm{ml}$ orally and $0.1 \mathrm{ml} \mathrm{i} / \mathrm{m}$ using the corresponding vaccine for each group. All birds were challenged with $0.5 \mathrm{ml}$ of NB culture $\left(3 \times 10^{8}\right.$ cells $)$ of a nalidixic acid resistant $\left(\mathrm{Nal}^{\mathrm{R}}\right)$ mutant of $S$. Enteritidis strain at week 5 of their age. Cloacal swabs were collected from all birds at $1 \mathrm{st}, 2 \mathrm{nd}, 3 \mathrm{rd}, 4 \mathrm{th}, 7 \mathrm{th}, 14 \mathrm{th}, 21 \mathrm{st}$ and $28 \mathrm{th}$ day post- challenge for a semi-quantitative estimation of bacterial shedding [7,8] of the challenge $S$. Enteritidis NalR by plating on BG agar supplemented with nalidixic acid $(20 \mu \mathrm{gm} / \mathrm{ml}-1)$ and novobioCin $(1 \mu \mathrm{gm} / \mathrm{ml}-1)$. On day 28 post-infection after collection of cloacal swabs all birds were slaughtered and their caecal contents were collected for a semiquantitative $S$. Enteritidis NalR count estimation.

\section{Second vaccination experiment}

This experiment was different from the first experiment only in the route of challenge and types of sample collected. The birds and groups were identical to those in the first experiment. As in experiment 1 
all birds in all groups were in ${ }^{\circ}$ Culated with $0.1 \mathrm{ml}$ of neat Avigard gut microflora (Microbial Developments Limited, UK), followed by intramuscular and oral vaccination as before as shown in Table 2 . When birds were 3 weeks of age the vaccination program was repeated as before. Subsequently, all birds were challenged intravenously via the wing vein with $0.1 \mathrm{ml}\left(1 \mathrm{x} 106\right.$ cells) of $S$. Enteritidis $\mathrm{Nal}^{\mathrm{R}}$ at 5 weeks age. Five birds from each group were selected randomly and killed at 1, 4, 6 and 8 days post-challenge. Immediately after killing each bird was sprayed with $70 \%$ ethanol and then spleen and liver samples were collected in pre-labelled, pre-weighed sterile universal bottles using separate sterile scissors and forceps. During sample collection all organs sampled were observed for any clinical signs. The caecal contents for each bird were then collected separately in pre-weighed sterile universal bottles. The three bottles for each bird were kept on ice prior to reweighing and diluting in $\mathrm{x} 9$ the weight of the sample in PBS. All tissue samples (liver and spleen) were kept on ice until they weighed and then proportional amounts (10xweight expressed as volume) of PBS (pH 7.2) were added into each tube. Each tissue portions was homogenized in a Griffiths tubes in PBS (pH 7.2) to obtain homogenous suspension ${ }^{2}$ prior to dilution for counting. This together with ax9 dilution of the caecal contents were used for bacterial count estimations.

Table I Vaccine administration regime and sample collection for vaccination experiment one (oral challenge)

\begin{tabular}{|c|c|c|c|c|c|}
\hline ay/Group & $\begin{array}{l}\text { Group I } \\
\text { in vivo formalin killed } \\
\text { bacteria }\end{array}$ & $\begin{array}{l}\text { Group II } \\
\text { in vivo sonicated } \\
\text { proteins }\end{array}$ & $\begin{array}{l}\text { Group III } \\
\text { in vitro formalin } \\
\text { killed bacteria }\end{array}$ & $\begin{array}{l}\text { Group IV } \\
\text { in vitro sonicated } \\
\text { proteins }\end{array}$ & $\begin{array}{l}\text { Group V } \\
\text { unvaccinated } \\
\text { control }\end{array}$ \\
\hline $\mathrm{I}$ & 0.Iml Avigard orally & $0.1 \mathrm{ml}$ Avigard orally & $0.1 \mathrm{ml}$ Avigard orally & 0.Iml Avigard orally & 0.I ml Avigard orally \\
\hline \multirow{2}{*}{5} & $\begin{array}{l}0.05 \mathrm{ml} \text { in vivo killed bacteria } \\
\mathrm{i} / \mathrm{m}\end{array}$ & $\begin{array}{l}\mathrm{a} 0.05 \mathrm{ml} \text { in vivo protiens } \\
\mathrm{i} / \mathrm{m}\end{array}$ & $\begin{array}{l}0.05 \mathrm{ml} \text { in vitro killed } \\
\text { bacteria } \mathrm{i} / \mathrm{m}\end{array}$ & $\begin{array}{l}0.05 \mathrm{ml} \text { in vitro proteins } \\
\mathrm{i} / \mathrm{m}\end{array}$ & $\begin{array}{l}0.05 \mathrm{ml} \text { sterile } \mathrm{NB} \\
\mathrm{i} / \mathrm{m}\end{array}$ \\
\hline & $\begin{array}{l}0.1 \mathrm{ml} \text { in vivo killed bacteria } \\
\text { orally }\end{array}$ & $\begin{array}{l}0.1 \mathrm{ml} \text { in vivo proteins } \\
\text { orally }\end{array}$ & $\begin{array}{l}0.1 \mathrm{ml} \text { in vitro killed } \\
\text { bacteria orally }\end{array}$ & $\begin{array}{l}0.1 \mathrm{ml} \text { in vitro proteins } \\
\text { orally }\end{array}$ & $\begin{array}{l}0.1 \mathrm{ml} \text { sterile NB } \\
\text { orally }\end{array}$ \\
\hline \multirow{2}{*}{21} & $\begin{array}{l}0.1 \mathrm{ml} \text { in vivo killed bacteria } \\
\mathrm{i} / \mathrm{m}\end{array}$ & $0.1 \mathrm{ml}$ in vivo proteins $\mathrm{i} / \mathrm{m}$ & $\begin{array}{l}0.1 \mathrm{ml} \text { in vitro killed } \\
\text { bacteria } \mathrm{i} / \mathrm{m}\end{array}$ & $\begin{array}{l}0.1 \mathrm{ml} \text { in vitro proteins } \\
\mathrm{i} / \mathrm{m}\end{array}$ & $0.1 \mathrm{ml}$ sterile $\mathrm{NB} \mathrm{i} / \mathrm{m}$ \\
\hline & $\begin{array}{l}0.3 \mathrm{ml} \text { in vivo killed bacteria } \\
\text { orally }\end{array}$ & $\begin{array}{l}0.3 \mathrm{ml} \text { in vivo proteins } \\
\text { orally }\end{array}$ & $\begin{array}{l}0.3 \mathrm{ml} \text { in vitro killed } \\
\text { bacteria orally }\end{array}$ & $\begin{array}{l}0.3 \mathrm{ml} \text { in vitro proteins } \\
\text { orally }\end{array}$ & $\begin{array}{l}0.3 \mathrm{ml} \text { sterile NB } \\
\text { orally }\end{array}$ \\
\hline 35 & \multicolumn{5}{|c|}{ All groups were challenged with $0.3 \mathrm{ml}$ contains $\left(5 \times 10^{8}\right) \mathrm{S}$. Enteritidis orally } \\
\hline Cloacal swabs & \multicolumn{5}{|c|}{ Cloacal swabs were collected from each birds in all groups for Salmonella count at day I,4,7, I4, 21 and 28 post challenge } \\
\hline $\begin{array}{l}\text { Caecal } \\
\text { contents }\end{array}$ & \multicolumn{5}{|c|}{$\begin{array}{l}\text { All birds were killed at week nine of their age and caecal contents were collected from each bird in all groups } \\
\text { for Salmonella count }\end{array}$} \\
\hline
\end{tabular}

Table 2 Vaccine administration regime and sample collection for vaccination experiment two (intravenous challenge)

\begin{tabular}{|c|c|c|c|c|c|}
\hline y/Group & $\begin{array}{l}\text { Group I } \\
\text { In Vivo formalin killed } \\
\text { bacteria }\end{array}$ & $\begin{array}{l}\text { Group II } \\
\text { In Vivo sonicated } \\
\text { proteins }\end{array}$ & $\begin{array}{l}\text { Group III } \\
\text { In Vitro formalin } \\
\text { killed bacteria }\end{array}$ & $\begin{array}{l}\text { Group IV } \\
\text { In Vitro sonicated } \\
\text { proteins }\end{array}$ & $\begin{array}{l}\text { Group V unvaccinated } \\
\text { control }\end{array}$ \\
\hline $\mathrm{I}$ & $0.1 \mathrm{ml}$ Avigard orally & $0.1 \mathrm{ml}$ Avigard orally & $0.1 \mathrm{ml}$ Avigard orally & $0.1 \mathrm{ml}$ Avigard orally & 0.I ml Avigard orally \\
\hline \multirow{2}{*}{5} & $\begin{array}{l}0.05 \mathrm{ml} \text { in vivo killed bacteria } \\
\text { i.m }\end{array}$ & $\begin{array}{l}\text { a } 0.05 \mathrm{ml} \text { in vivo protiens } \\
\text { i.m }\end{array}$ & $\begin{array}{l}0.05 \mathrm{ml} \text { in vitro killed } \\
\text { bacteria i.m }\end{array}$ & $\begin{array}{l}0.05 \mathrm{ml} \text { in vitro protiens } \\
\text { i.m }\end{array}$ & $0.05 \mathrm{ml}$ sterile NB i.m \\
\hline & $\begin{array}{l}0.1 \mathrm{ml} \text { in vivo killed bacteria } \\
\text { orally }\end{array}$ & $\begin{array}{l}0.1 \mathrm{ml} \text { in vivo proteins } \\
\text { orally }\end{array}$ & $\begin{array}{l}0.1 \mathrm{ml} \text { in vitro killed bacteria } \\
\text { orally }\end{array}$ & $\begin{array}{l}0.1 \mathrm{ml} \text { in vitro proteins } \\
\text { orally }\end{array}$ & $0.1 \mathrm{ml}$ sterile NB orally \\
\hline \multirow{2}{*}{21} & $\begin{array}{l}0.1 \mathrm{ml} \text { in vivo killed bacteria } \\
\text { i.m }\end{array}$ & $\begin{array}{l}0.1 \mathrm{ml} \text { in vivo proteins } \\
\text { i.m }\end{array}$ & $\begin{array}{l}0.1 \mathrm{ml} \text { in vitro killed bacteria } \\
\text { i.m }\end{array}$ & $\begin{array}{l}0.1 \mathrm{ml} \text { in vitro proteins } \\
\text { i.m }\end{array}$ & $0.1 \mathrm{ml}$ sterile NB i.m \\
\hline & $\begin{array}{l}0.3 \mathrm{ml} \text { in vivo killed bacteria } \\
\text { orally }\end{array}$ & $\begin{array}{l}0.3 \mathrm{ml} \text { in vivo proteins } \\
\text { orally }\end{array}$ & $\begin{array}{l}0.3 \mathrm{ml} \text { in vitro killed bacteria } \\
\text { orally }\end{array}$ & $\begin{array}{l}0.3 \mathrm{ml} \text { in vitro proteins } \\
\text { orally }\end{array}$ & $0.3 \mathrm{ml}$ sterile NB orally \\
\hline
\end{tabular}

$35 \quad$ All birds in all groups Challenged intravenously with $0.1 \mathrm{ml}$ containing $\left(|x| 0^{6}\right)$ Live S. Enteritidis

Post challenge Five randomly selected birds from each group were killed at day I, 4, 6 and 8 post infections, tissue portion of their spleen and liver sample plus caecal contents were collected for Salmonella count.

Table 3 Effect of vaccinating with formalin-killed S. Enteritidis and whole-cell sonicated protein preparation on faecal excretion of S. Enteritidis NalR (challenge strain),results obtained from direct plates; plus results of BGA enriched plates shown number of S. Enteritidis NalR positive birds (positivity \%), from cloacal and caecal sample collected at different time points post infections, chicks were orally inoculated

\begin{tabular}{|c|c|c|c|c|c|c|c|c|c|c|c|}
\hline \multicolumn{12}{|c|}{$\begin{array}{l}\text { Percentage of chickens ( } 20 \text { birds per group) } \\
\text { birds (Positivity \%) from enriched plates at }\end{array}$} \\
\hline \multirow{2}{*}{ Sample } & \multirow{2}{*}{ Days PI } & \multicolumn{2}{|c|}{ In Vivo Killed Bacteria } & \multicolumn{2}{|c|}{ In Vivo Proteins } & \multicolumn{4}{|c|}{ In Vitro Killed Bacterialn Vitro Proteins } & \multicolumn{2}{|c|}{ Unvaccinated } \\
\hline & & Direct & Enriched & Direct & Enriched & Direct & Enriched & Direct & Enriched & Direct & Enriched \\
\hline & & $\geq 50 \geq 1$ & Birds( No\& \%) & $\geq 50 \geq 1$ & Birds( No\& \% & $\geq 50 \geq 1$ & Birds( No\& \%) & $\geq 50>1$ & Birds(No\& \%) & $\geq 50 \geq 1$ & Birds(No\& \%) \\
\hline & 1 & $0 \% \quad 0 \%$ & $13(66 \%)$ & $0 \% \quad 10 \%$ & $10(52 \%)$ & $5 \% 33 \%$ & $9(43 \%)$ & $0 \% \quad 16 \%$ & $5(26 \%)$ & $0 \% \quad 20 \%$ & $69(45 \%)$ \\
\hline & 4 & $0 \% \quad 24 \%$ & $9(43 \%)$ & $14 \% 38 \%$ & $16(81 \%)$ & $0 \% \quad 10 \%$ & II (57 \%) & $0 \% \quad 16 \%$ & $5(26 \%)$ & $0 \% \quad 25 \%$ & 6 10 (52 \%) \\
\hline \multirow[t]{4}{*}{ Cloacal swabs } & 7 & $0 \% \quad 29 \%$ & $10(52 \%)$ & $5 \% \quad 5 \%$ & $7(33 \%)$ & $0 \% \quad 5 \%$ & $12(62 \%)$ & $0 \% \quad 0 \%$ & $6(32 \%)$ & $5 \% \quad 5 \%$ & $10(50 \%)$ \\
\hline & 14 & $0 \% \quad 0 \%$ & $6(29 \%)$ & $0 \% \quad 0 \%$ & $3(14 \%)$ & $5 \% \quad 5 \%$ & 4 (19\%) & $0 \% \quad 0 \%$ & $0(0 \%)$ & $5 \% \quad 10 \%$ & 3 (15\%) \\
\hline & 21 & $0 \%$ & $4(19 \%)$ & $0 \% \quad 0 \%$ & $2(10 \%)$ & $0 \% \quad 0 \%$ & 3 (14 \%) & $0 \% \quad 0 \%$ & $0(0 \%)$ & $5 \% \quad 15 \%$ & 4 (20 \%) \\
\hline & 28 & $0 \% \quad 0 \%$ & $3(14 \%)$ & $0 \% \quad 0 \%$ & $2(10 \%)$ & $0 \% \quad 0 \%$ & $2(10 \%)$ & $0 \% \quad 0 \%$ & $0(0 \%)$ & $0 \% \quad 15 \%$ & $64(20 \%)$ \\
\hline Caecal content & $t 28$ & $0 \% \quad 0 \%$ & $0(0 \%)$ & $0 \% \quad 0 \%$ & $0(0 \%)$ & $0 \% \quad 0 \%$ & $0(0 \%)$ & $0 \% \quad 0 \%$ & $0(0 \%)$ & $5 \% \quad 20 \%$ & 67 (35 \%) \\
\hline
\end{tabular}


Table 4 The protective effect of formalin-killed bacteria and protein preparation from S. Enteritidis harvested from chickens in vivo or nutrient broth in vitromeasured by liver and spleen counts of chicks inoculated intravenously by the parent strain. Log $_{10}$ mean viable counts of Salmonella per ml of homogenized liver tissue of 5 birds from each group/time poin

\begin{tabular}{|c|c|c|c|c|c|c|c|c|c|c|c|c|c|c|c|c|c|c|c|c|c|c|c|c|c|c|c|}
\hline \multirow{3}{*}{$\begin{array}{l}\text { Days } \\
\text { PI }\end{array}$} & \multicolumn{6}{|c|}{ In Vivo Killed Bacteria } & \multicolumn{6}{|c|}{ In Vivo Proteins } & \multicolumn{4}{|c|}{ In Vitro Killed Bacteria } & \multicolumn{5}{|c|}{ In Vitro Proteins } & \multicolumn{6}{|c|}{ Unvaccinated } \\
\hline & \multicolumn{3}{|c|}{ Liver } & \multicolumn{3}{|l|}{ Spleen } & \multicolumn{3}{|c|}{ Liver } & \multicolumn{3}{|c|}{ Spleen } & \multicolumn{2}{|c|}{ Liver } & \multicolumn{2}{|c|}{ Spleen } & \multicolumn{2}{|l|}{ Liver } & & \multicolumn{2}{|l|}{ Spleen } & \multicolumn{3}{|l|}{ Liver } & \multicolumn{3}{|c|}{ Spleen } \\
\hline & $\log _{10}$ & SE & $\mathbf{P}$ & $\log _{10}$ & SE & $\mathbf{P}$ & $\log _{10}$ & SE & $\mathbf{P}$ & $\log _{10}$ & SE & $\mathbf{P}$ & $\log$ & ${ }_{0}$ SE P & $\log _{1}$ & ${ }_{0}$ SE P & $\log _{10}$ & ${ }_{0} \mathrm{SE}$ & $\mathbf{P}$ & $\log _{10}$ & SE $P$ & $\log _{10}$ & SE & $\mathbf{P}$ & $\log _{10}$ & SE & $\mathbf{P}$ \\
\hline I & 3.9 & 0.1 & 0 & 5.1 & 0.04 & 0.23 & 3.8 & 0.1 & 0.07 & 5 & 0.03 & 0.2 & 4 & 0.1 & 4.6 & 0.2 & 4 & 0.1 & 0.03 & 4.7 & 0.10 .7 & 3.4 & 0.08 & - & 4.8 & 0.15 & - \\
\hline 4 & 3.6 & 0.1 & 0.08 & 5.3 & 0.15 & 0.5 & 3.5 & 1 & 0.08 & 5.2 & 0.1 & 0.1 & 3.2 & 0.10 .18 & 5.2 & 0.10 .1 & 3.1 & 0.1 & 0.2 & 5.1 & 0.10 .2 & 2.3 & 0.5 & - & 4.7 & 0.19 & - \\
\hline 6 & 2.6 & 0.1 & 0.04 & 4.9 & 0.13 & 0.1 & 2.6 & 0.2 & 0.08 & 4.8 & 0.1 & 0.08 & 3 & 0.04 & 4.9 & 0.20 .1 & 3 & 0.1 & 0.02 & 4.8 & 0.10 .1 & 0.9 & 0.6 & - & 3.1 & 0.48 & - \\
\hline 8 & 2 & 0 & 0.1 & 4.5 & 0.6 & 0.09 & 2.06 & 0.06 & 0.8 & 4 & I & 0.8 & 2.2 & 0.10 .4 & 4.9 & 0.30 & I & 0.2 & 0.12 & 4.1 & 0.20 .7 & 2.3 & 0.7 & - & 4 & 0.13 & - \\
\hline
\end{tabular}

Table 5 The effect of formalin-killed bacteria and protein preparation of S. Enteritidis harvested from in vivo and in vitro conditions on colonisation of chicken caeca with lactose fermentor bacteria when challenged intravenously by the parent strain S. Enteritidis NalR. (Average viable counts log ${ }_{10}$ per Iml of caecal contents).

\begin{tabular}{|c|c|c|c|c|c|c|c|c|c|c|c|c|c|c|c|}
\hline \multicolumn{4}{|c|}{ Days post In Vivo Killed Bacteria } & \multicolumn{3}{|c|}{ In Vivo Proteins } & \multicolumn{3}{|c|}{ In Vitro Killed Bacteria } & \multicolumn{3}{|c|}{ In Vitro Proteins } & \multicolumn{3}{|c|}{ Unvaccinated } \\
\hline infection & $\log _{10}$ & SE & $\mathbf{P}$ & $\log _{10}$ & SE & $\mathbf{P}$ & $\log _{10}$ & SE & $\mathbf{P}$ & $\log _{10}$ & SE & $\mathbf{P}$ & $\log _{10}$ & SE & $\mathbf{P}$ \\
\hline I & 2 & 0 & 0.3 & 2 & 0 & 0.07 & 4.7 & 0.2 & 0.04 & 3 & 0.2 & 0.6 & 2.7 & 0.7 & \\
\hline 4 & 2.6 & 0.37 & 0 & 2.5 & 0.3 & 0.08 & 4.8 & 0.2 & 0 & 2.3 & 0.2 & 0.18 & 2 & 0 & - \\
\hline 6 & 2.7 & 0.28 & 0.9 & 2.6 & 0.2 & 0.08 & 4.9 & 0.2 & 0.01 & 2.8 & 0.2 & 0.64 & 2.65 & 0.4 & - \\
\hline 8 & 2.9 & 0.56 & 0.15 & 2.9 & 0.5 & 0.3 & 4 & 0.8 & 0.1 & 3.2 & 0.8 & 0.61 & 2.46 & 0.3 & - \\
\hline
\end{tabular}

SE, Standard Error; P, P value.

\section{Bacterial Culture and Count}

\section{Enumeration of bacteria in chicken faeces (Experiment I)}

After collection of all swabs $2 \mathrm{ml}$ selenite broth (Oxoid, CM0395) were added to each tube, followed by brief vortexing. Once they were mixed, each swab was placed in a standard manner on brilliant green agar plate (BGA) supplemented with nalidixic acid $(20 \mu \mathrm{gm} /$ $\left.\mathrm{ml}^{-1} 0\right)$ and novobi ${ }^{\circ} \mathrm{Cin}\left(1 \mu \mathrm{gm} / \mathrm{ml}^{-1}\right)$. BGA in a standard manner. ${ }^{9}$ The in $^{\circ}$ Culated plates and the selenite broths were incubated overnight at $37^{\circ} \mathrm{C}$. Then the swabs were left into selenite broth tubes for overnight incubation at $37^{\circ} \mathrm{C}$ prior to plating on $\mathrm{BGA}$, to encourage the growth of Salmonellae and inhibit the growth of other flora. Then the overnight incubated swabs were plated again on the antibioticcontaining BGA media and incubated overnight at $37^{\circ} \mathrm{C}$. Plates in ${ }^{\circ}$ Culated directly were read and observed for Salmonella growth using a semi-quantitative estimation of faecal shedding and caecal colonization of Salmonella from infected chickens..$^{1,7,10-12}$ Next day the enrichment plates were also checked for Salmonella growth. Xylose Lysine Deoxycholate (XLD) media (Oxoid, CM0469) was used as a confirmatory test for any Salmonella growth. Suspect colonies were sub-cultured on this media and incubated overnight at $37^{\circ} \mathrm{C}$, and the plates were checked for black colonies indicating Salmonella as a result of $\mathrm{H}_{2} \mathrm{~S}$ production, in addition to slide agglutination tests.

\section{Bacterial enumeration in tissues samples (Experiment II)}

The bacterial count of $S$. Enteritidis $\mathrm{Nal}^{\mathrm{R}}$ in spleen, liver and caecal contents for the 5 birds of each group (at day 1, 4, 6 and 8 post challenge), were estimated by serial dilution and plating aliquots of dilutions. ${ }^{9}$ Aliquots of each dilution were plated on BGA plates supplemented with nalidixic acid $\left(20 \mu \mathrm{gm} / \mathrm{ml}^{-1}\right)$ and novobi ${ }^{\circ} \mathrm{Cin}(1$ $\left.\mu \mathrm{gm} / \mathrm{ml}^{-1}\right)$ and incubated overnight at $37^{\circ} \mathrm{C}$. Bacterial colonies were counted and the viable count converted into $\log _{10}$ numbers. The Xylose lysine Deoxycholate medium XLD (Oxoid, CM0469) and slide agglutination tests were also used as confirmatory test to confirm any Salmonella growth.

\section{Data Analysis}

\section{Analysis of data obtained from experiment I}

Cloacal swabs were taken from each bird two days previous to challenge in ${ }^{\circ}$ Culation for culture to guarantee that the chicks are free from Salmonellae. Differences in percentage excretion rates between groups of birds were compared using $\chi^{2}$, and this was considered as statistically significant if the $\mathrm{P}$ value was $(<0.05)$.

\section{Analysis of data obtained from Experiment II}

As in experiment I Cloacal swabs were taken from each bird two days before being challenged for culture to guarantee that the chicks are free from Salmonellae. The bacterial counts of $S$. Enteritidis $\mathrm{Nal}^{\mathrm{R}}$ (challenge) of the tissues (spleen and liver) and caeca in different groups on BGA plate, in different time points were recorded and the $\mathrm{P}$ value of each group compared to the control group were calculated using Student's unpaired t test (Microsoft Office 2007). A P value of $(<0.05)$ was considered as statistically significant.

\section{Results}

It was decided to carry out experimental in vivo infection using 1-day old chicks primarily to avoid the development of intestinal microflora, which would be likely to have a significant effect on interference in interpreting the patterns of protein expression in $S$. Enteritidis as well as to enable the bacterium of interest (S. Enteritidis) to multiply extremely well in the absence of competitive colonizers. ${ }^{2,13}$ Using birds aged from 2-6 weeks is the best model to study Salmonella colonization of chicken, as their gut flora is mature (Barrow, personnel communication), but for studying Salmonella proteins this might give a false results due to cross contaminations of gut flora. The model used therefore, uses colonization during infection in newly-hatched chickens and which might ${ }^{\circ} \mathrm{Ccur}$ in a hatchery. Interestingly, a study of Campylobacter jejuni gene transcription using a similar model revealed a similarity between this model and birds that had already established their flora. ${ }^{13}$ On the other hand, other researchers have used a different model (spectinomycin-treated mouse) with E. coli..$^{14,15}$ So there is good reason to suppose that the protein expression of Salmonella in newly hatched chickens may also be similar to that in old chicks with established flora. In addition, the caeca empty and fill several times a day, the phases of growth of the in ${ }^{\circ}$ Culated bacteria in individual birds may be different. However, it will be clear that major differences in transcription between in vivo and in vitro culture will be identified. A 
protein analysis of $S$. Enteritidis in the caeca of 1-day old checks (in vivo) together with a comparison with nutrient broth medium (in vitro) was used to detect changes in the pattern of protein expression during infection and in particular to identify proteins that enable this strain to colonise the caeca. It was decided to use $S$. Enteritidis proteins extracted from stationary phase as the protein concentration of mid $\log$ phase was very low. The problems ass ${ }^{\circ}$ Ciated with harvesting in vitro grown cultures also apply, particularly relating to a synchronicity of growth. The issues ass ${ }^{\circ}$ Ciated with cultures of this sort are that (i) bacterial growth is asynchronous. However, bacterial growth in vivo will also be asynchronous, and (ii) the relevance of using a rich nutrient broth culture as a control can be questioned. However, there is no truly rational way of establishing a control for in vivo growth and previous work, ${ }^{16}$ indicates that our approach is an appropriate approach. We compare the immunogenicity of bacteria (S. Enteritidis) harvested from the intestine with those grown in vitro in nutrient broth cultures. The preparations would include (i) formalin-killed whole bacteria harvested from the caeca, (ii) whole cellular proteins prepared from in vivo-cultured bacteria and (iii) in vitro-grown bacteria in NB (iv) whole cellular proteins prepared from in vitrogrown bacteria in NB all of which would be tested for their ability to protect against Salmonella colonization in chicken.

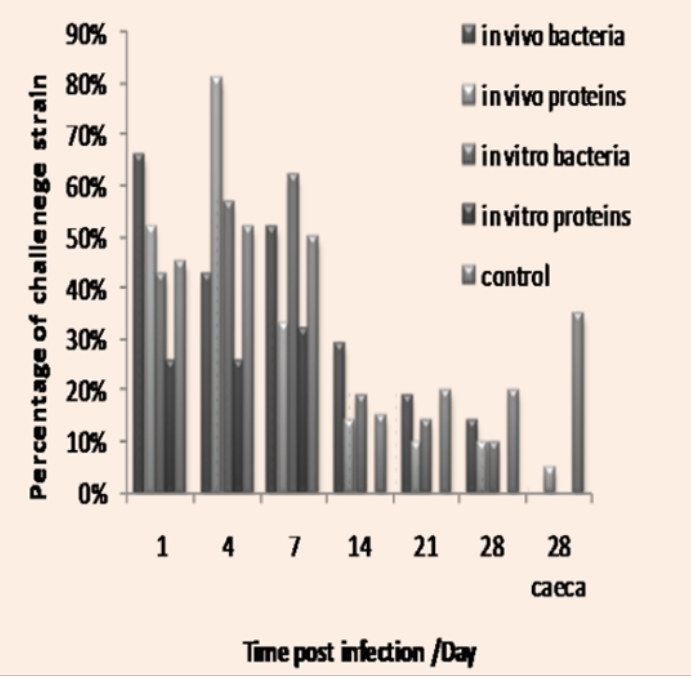

Figure I Faecal excretion of challenge $S$. Enteritidis strain following vaccination with formalin killed Salmonella harvested from chickens (in vivo) or nutrient broth (in vitro) plus Salmonella proteins produced from bacteria cultured either in chickens (in vivo) or in nutrient broth (in vitro) compared with unvaccinated control, this figure also shown that no growth of any Salmonella were detected in caecal contents of all treated groups 4 weeks post infection.

\section{Quality control of the vaccine}

No growth was detected after culturing the formalized $S$. Enteritidis PT4, as well as protein sonicates harvested from both in vivo and in vitro environments on MacConkey and nutrient agar plates for overnight at $37^{\circ} \mathrm{C}$.

\section{Results for experiment I (orally challenged chicks)}

No Salmonella organisms were isolated from the chickens on receipt. The percentage excretion rates of the challenge Salmonella strain in the different groups are shown in Table 3. When Salmonella was cultured by direct plating if the colony numbers present per plate was 1 or more this was designated as $\geq 1$, while when they were 50 colonies or more this was designated as $\geq 50 .{ }^{17}$ The bacteria cultured by enrichment followed by plating were shown as the percentage of positive swabs, which had been confirmed by XLD agar and slide agglutination tests as shown in Table 3 .

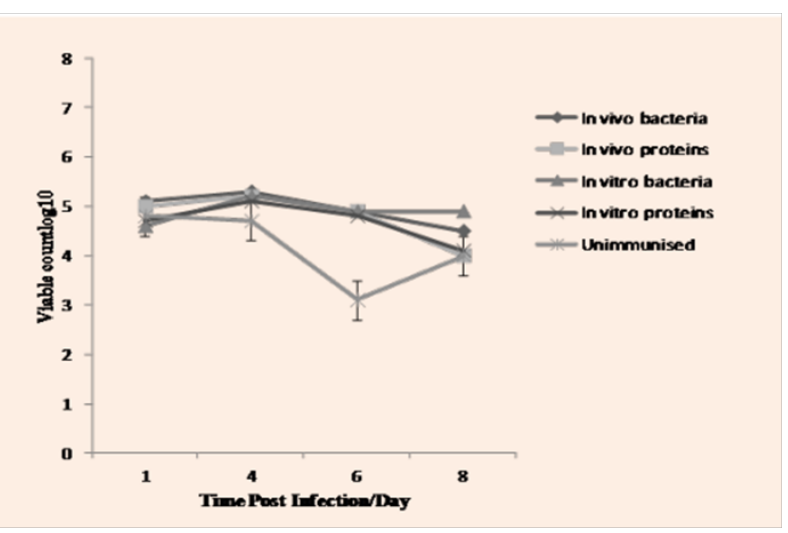

Figure 2 The number of Salmonella $\log _{10} \mathrm{cfu} / \mathrm{ml}$ in chicken's spleen tissue in the groups of birds (each of 20 birds) treated with either S. Enteritidis whole cellular in vivo and in vitro sonicated proteins preparation or in vivo and in vitro formalin killed S. Enteritidis compared with unimmunised control post challenge with parent strain (S. Enteritidis NaIR) inoculated intravenously.

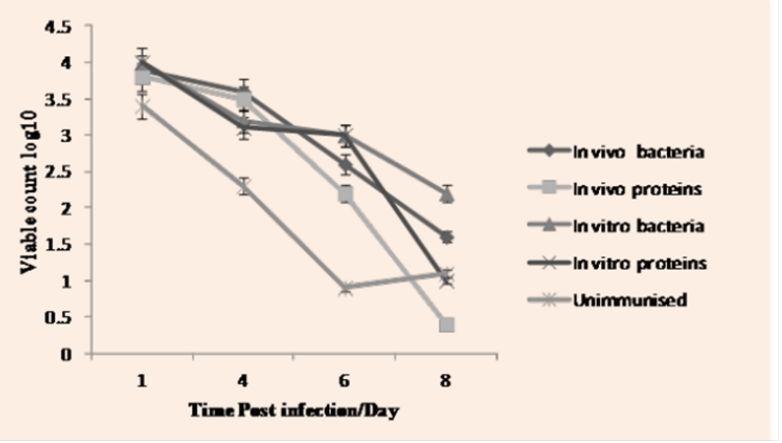

Figure 3 The number of Salmonella $\log _{10} \mathrm{cfu} / \mathrm{ml}$ in liver tissue in the groups of birds treated with either S. Enteritidis whole cellular in vivo and in vitro sonicated proteins preparation or in vivo and in vitro formalin-killed $S$. Enteritidis compared with unimmunised control post challenge with parent strain (S. Enteritidis NaIR) intravenously.

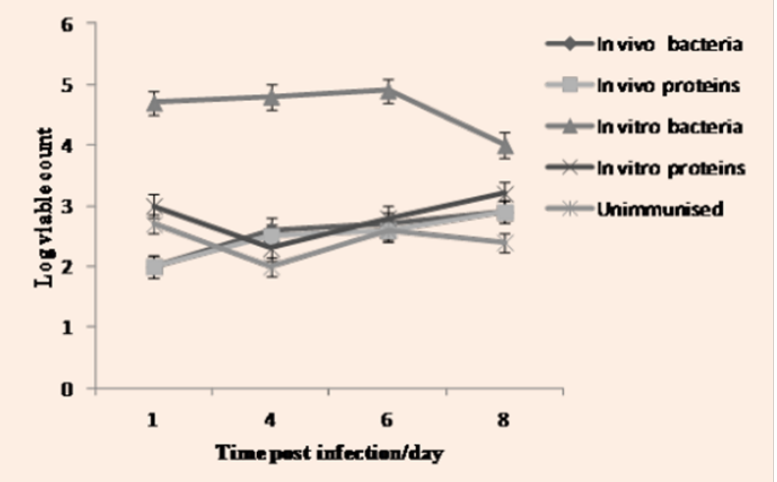

Figure 4 The number of lactose fermentor bacteria $\log _{10}$ cfu/ml-I in caecal contents in the five groups of birds treated with in vivo or in vitro protein preparations of S.Enteritidis plus formalin killed bacteria harvested from in vivo and in vitro conditions compared with unimmunised group at Ist, 4th, 6th and 8th day post intra-venous infection with challenge strain S. Enteritidis NaIR.

Based on evaluation of the results of all samples collected (either caecal contents or cloacal swabs), the percentage of chickens positive for $S$. Enteritidis $\mathrm{Nal}^{\mathrm{R}}$ challenge strain for the first day postinfection was $66 \%$ and $43 \%$ for the birds in group one and three which were treated with formalin killed bacteria harvested from in 
vivo and in vitro environment respectively, whereas the percentage of faecal excretion of the challenge strain in group two and four which were treated with in vivo and in vitro sonicated proteins preparation respectively were $52 \%$ and $26 \%$, compared with $45 \%$ in untreated control (group five). There were a variable change of these percentages at $4^{\text {th }}$ day post infection as the percentage remained same $(26 \%)$ in group four which had been treated with in vitro sonicated proteins while in group one, two and three the percentages were $43 \%, 81 \%$ and $57 \%$ respectively, with $52 \%$ in the control group. Subsequently, one week post infection the corresponding values were $52 \%, 33 \%, 62 \%$ and $32 \%$ in treated groups from one to four respectively and $50 \%$ in the unvaccinated control group. Then there was a noticeable decrease in the percentages of faecal excretion in all groups two weeks post infection as the percentages were $29 \%, 14 \%$, $19 \%, 0 \%$ and $15 \%$ in groups from one to five respectively. Moreover, three weeks post challenge the percentage of positive birds' faecal excretion was $19 \%$ for the in vivo killed vaccine group (group one) and $10 \%$ for the in vivo sonicated proteins (group two), and it was $14 \%$ for the in vitro killed vaccine group ( group three), while there was no faecal excretion $(0 \%)$ in group four which was vaccinated with in vitro protein preparation with no difference from 2 nd week post infection compared with $(20 \%)$ of unvaccinated control group. There were no noticeable difference in faecal excretion in week four post infection with percentages $14 \%, 10 \%, 10 \%$, and $20 \%$ in groups from 1 to five respectively. Figure 1 below illustrate the percentages of chickens' faecal exertion of $S$. Enteritidis $\mathrm{Nal}^{\mathrm{R}}$ (challenge strain) at different time points $\left(1^{\text {st }}, 4^{\text {th }}, 7^{\text {th }}, 14^{\text {th }}, 21^{\text {st }}\right.$, and $\left.28^{\text {th }}\right)$ days post infection. In summary, both in vitro and in vivo protein preparations had a much greater immunization effect than that produced by killed bacteria. The $P$ values were $\left(\chi^{2}=28.3\right.$. $\left.P<0.001\right)$ and $\left(\chi^{2}=16.77\right.$. $\left.P<0.001\right)$ for the in vitro and in vivo proteins treated groups respectively, which were considered as statistically significant. The in vivo protein preparation unexpectedly had a lower immunogenic effect than did the in vitro proteins preparation. From the caecal samples collected at week four post infection Salmonella was detected only in unimmunised control (group five), while no growth of any Salmonella were observed in all treated groups $(<1 \times 102 \mathrm{cfu} / \mathrm{ml})$ as shown in Table 3 above and Figure 1 below.

\section{Results for experiment II (Intravenously challenged chicks)}

The results presented in Table 4 shows the averages ofLog $_{10}$ Salmonellae counts in liver and spleen of five chickens taken at different time points post-infection from the four groups of immunised birds plus the control group with the $P$ values. No Salmonellae were detected in caecal contents of any bird from the group immunised with sonicated proteins, or groups treated with formalin-killed bacteria although some other bacterial growth such as E. coli, Klebsiella were observed as illustrated in Table 5 and Figure 4. Salmonellae challenge organisms were detected in the control group. Moreover, as shown in Figure 2 below when chickens were challenged intravenously with parent $S$. Enteritidis $\mathrm{Nal}^{\mathrm{R}}$, the viable counts $\left(\log _{10}\right)$ of Salmonellae in the spleen on the 1st day post-infection were 5.1, 5, 4.6 and 4.7 $\mathrm{cfu} / \mathrm{ml}$ in group I, II, III and IV which were vaccinated with in vivo killed bacteria, in vivo proteins, in vitro killed bacteria and in vitro proteins respectively, whereas the count in unimmunised control group (V) was $4.8 \mathrm{cfu} / \mathrm{ml}$. Surprisingly, the count of Salmonellae in spleen tissues on the $4^{\text {th }}$ day post-infection in all immunised groups (Log 5.3, 5.2, 5.2 and $5.1 \mathrm{cfu} / \mathrm{ml}$ ) respectively, were all higher than unimmunised control group which was $\log 4.7 \mathrm{cfu} / \mathrm{ml}$, with only very small variations of Salmonellae count on the $6^{\text {th }}$ day post infection 4.9, $4.8,4.9$ and $4.8 \mathrm{cfu} / \mathrm{ml}$ for the groups immunised with in vivo killed bacteria, in vivo proteins, in vitro killed bacteria and in vitro proteins respectively, compared with $3.1 \mathrm{cfu} / \mathrm{ml}$ in control group. There were no big differences observed in chicken spleen colonization with Salmonellae on the $8^{\text {th }}$ day post challenge in all treated groups as well as unimmunised control group with bacterial count $\log _{10} 4.5,4.0$, $4.9,4.1$ and $4.0 \mathrm{cfu} / \mathrm{ml}$ respectively. At 1 day post-infection the bacterial count in liver were Log 3.9 and $4.0 \mathrm{cfu} / \mathrm{ml}$ for the birds in group I and III, which were immunised with in vivo and in vitro formalin-killed bacteria respectively, whereas the Salmonellae count in groups two and four immunised with in vivo and in vitro proteins preparation were $\log 3.8$ and $4.0 \mathrm{cfu} / \mathrm{ml}$. This result was unexpected as the counts in all vaccinated groups were again higher than that of unimmunised birds ( $\log 3.4 \mathrm{cfu} / \mathrm{ml})$ as illustrated in Table 4 below. On this day the $P$ value of Salmonellae in liver tissue in all vaccinated groups was $P<0.00, P<0.07, P<0.01$ and $P<0.03$ respectively compared to the unimmunised control. Salmonella countsin liver on $1^{\text {st }}, 4^{\text {th }}$, $6^{\text {th }}$ and $8^{\text {th }}$ day post infection steadily decreased in all vaccinated and unimmunised birds as shown in Table 4 and Figure 3 below. Furthermore, the $\log _{10}$ Salmonella counts in liver on the $4^{\text {th }}$ day post infection were 3.6 and 3.2 in groups vaccinated with in vivo and in vitro killed bacteria respectively, while in both groups vaccinated with in vivo and in vitro proteins preparation the Log counts were 3.5 and 3.1 respectively compared with 2.3 in unimmunised birds, with $P$ value $(P<0.08, P<0.08, P<0.18, P<0.2)$ in the groups treated with in vivo killed bacteria, in vivo proteins, in vitro killed bacteria and in vitro proteins respectively. On day 6 post challenge the mean Salmonellae $\log _{10}$ count was 2.6 in groups I and II which were in $^{\circ} \mathrm{Culated}$ with either in vivo bacteria or in vivo proteins, while in groups III and IV, which were in ${ }^{\circ}$ Culated with in vitro killed Salmonellae and in vitro proteins respectively, the Salmonellae $\log _{10}$ count was 3.0 in both group. Consequently, however, on the last day of sample collection ( the $8^{\text {th }}$ day post infection), the mean $\log _{10}$ Salmonellae count in liver was 2.0 and 2.2 for in vivo and in vitro killed bacteria respectively, 2.06 and 1.0 for in vivo and in vitro protein vaccines respectively and 2.3 for unimmunised birds as shown in Figure 3 below. In addition, bacterial counting was performed on caecal contents for all birds and with the exception of some lactose fermentor bacteria cultured from different group birds' caeca, no Salmonellae were detected $(<\log 2 \mathrm{cfu} / \mathrm{ml})$ in caecal contents of any bird.

However, 1 day post infection birds vaccinated with in vitro formalin killed showed the highest bacterial count $\left(\log _{10} 4.7 \mathrm{cfu} /\right.$ $\mathrm{ml})$ of lactose fermentors in their caecal contents with $P$ value $(P<0.04)$, followed by the group immunised with in vitro proteins which produced counts of $\log 3.0 \mathrm{cfu} / \mathrm{ml}$ with $P$ value $(P<0.6)$. On $4^{\text {th }}$ day post-infection the birds immunised with in vitro bacteria again showed the highest count ( $\log 4.8 \mathrm{cfu} / \mathrm{ml})$ followed by the groups immunised with in vivo bacteria and in vivo proteins which had mean counts of $\log 2.6 \mathrm{cfu} / \mathrm{ml}$ and $2.5 \mathrm{cfu} / \mathrm{ml}$ respectively as illustrated in Table 5 and Figure 4 . Caecal contents that showed no bacterial growth were considered as $(<\log 2 \mathrm{cfu} / \mathrm{ml})$ which means that the average of bacterial count is less than the limit of detection.

\section{Discussion}

Control of Salmonella infections in chickens is crucially important towards the aim of reduction of human food-poisoning salmonellosis. Legislation has been introduced by the European Union (Directive 2003/99/EC, Regulation 2160/2003) to monitor the most important Salmonella serovars with timetabled requirements for submission of action plans to control infections in major hosts, particularly pigs and poultry. As a part of this both live and inactivated vaccine are now used in many countries both in the EU and around the world. Nevertheless, live vaccines used in the EU are produced by chemical mutagenesis, and are antibiotic resistant. 
In the present study four types of vaccine were produced from $S$. Enteritidis PT4. The vaccines were a sonicated protein preparation from (i) bacteria harvested from in vivo- and (ii) from in vitro-cultured bacteria, plus formalin-killed bacteria harvested from the (iii) in vitro and (iv) the in vivo environment. The hypothesis was that both types of vaccines (either killed bacteria or protein preparation) prepared from Salmonellae harvested directly from the chicken intestine would be more immuno-protective than those cultured in vitro in nutrient broth, as they were prepared from the same environment where protection would be required (gut). The protective effect of formalin-killed bacteria plus protein preparations was assessed for their effect in chickens against colonisation and systemic invasion of the homologous challenge strain. Caecal colonisation was assessed by cloacal swabbing with a semi-quantitative method of enumeration which has been used extensively for large groups of birds ${ }^{10,11,18}$ Some authors, ${ }^{19-21}$ have shown that killed Salmonella vaccines induce just partial immune protection in poultry. Newly hatched chickens have no established gut flora which is why Avigard gut flora was provided on day one to make available a gut flora that is naturally present in adult birds ${ }^{22}$ and to reduce the level of coloisation to something more closely resembling that of the adult.

After vaccination Cloacal swabbing has demonstrated to be a useful semi-quantitative method for the faecal shedding of Salmonellae and estimation of caecal colonisation when chickens experimentally infected, as found previously. ${ }^{10,11,18}$ However, when direct Salmonella counts were made from caecal contents and compared at the end of vaccination experiment I (orally challenged), there appeared little correlation with the semi-quantitative measures determined by Cloacal swabbing. This phenomenon is well known, and is probably ass ${ }^{\circ}$ Ciated with intermittent caecal evacuation. ${ }^{23}$ In the present work when birds were challenged orally to assess Salmonella caecal colonisation by Cloacal swabbing (Experiment I), the response was great enough to significantly prevent caecal colonisation completely in the groups of birds challenged orally with a virulent $S$. Enteritidis $\mathrm{Nal}^{\mathrm{R}}$ strain when the vaccine was the protein preparation harvested from either the in vivo condition (in chickens) or in vitro (in nutrient broth culture). The results show that protection by both in vitro and in vivo proteins preparation were statistically significant $(P<0.001)$ in their ability to protect against Salmonella colonization. However, the level of protective immunity induced by the in vitro protein preparation was higher than that induced by the in vivo preparation.

The good level of protection induced by the in vitro preparation is in agreement with the previous work conducted by Khan et al., ${ }^{6}$ who found that outer membrane proteins of Salmonella when in ${ }^{\circ} \mathrm{Culated}$ with adjuvant are effective against $S$. Enteritidis in chickens. ${ }^{6}$ In contrast, the protection produced by formalin-killed Salmonella harvested from either in vitro or in vivo conditions when used as vaccine candidate in chickens was found to be statistically insignificant. This is in agreement with other researchers who found that proteins (OMPs) gave better protection than formalin-killed bacteria. ${ }^{25}$ For other organisms, such as $S$. Gallinarumand Pasteurella mult ${ }^{\circ}$ Cida, OMPs also give better protection than whole bacterins or sonicated cells. ${ }^{25,26}$ Immunization with Helicobacter whole-cell extracts or purified components also effectively prevented $H$. pylori infection in mice. ${ }^{27-30}$ Protein subunit antigens induce production of antibodies and can also induce cell-mediated immunity, resulting in long-lasting protection against bacterial infections. ${ }^{31}$

At $4^{\text {th }}$ week post infection no Salmonellae were detected from caecal swabs from the vaccinated groups $\left(<1 \times 10^{2} \mathrm{cfu} / \mathrm{ml}\right)$ compared with unimmunised group that show the percentage of Salmonellae positive to be $35 \%$.However, these results showed that the better protection induced by the proteins from the in vitro cultured bacteria in comparison with the proteins from the in vivo harvest bacteria were unexpected, since it was anticipated that the in vivo preparation would have been at least as immunogenic as the in vitro preparation, as the protein concentrations of both in vivo and in vitro preparation were similar. However, the reason that the effectiveness of the in vivo preparation as vaccine was less than that of the in vitro preparation may have been the result of degradation of the proteins harvested from chicken caeca by avian proteases as discussed earlier (Chapter 4). The in vivo preparation would have contained a number of antigens that are expressed in the very earliest stages of infection and these may have been important. Moreover, certain genes that encode some important antigens such as LPS and flagella were down-regulated in the intestine of chickens. ${ }^{17,32}$

It is also known that genes ass ${ }^{\circ}$ Ciated with invasion and early infection, including Salmonella Pathogenicity Island 1 (SPI1) genes are up-regulated in the intestine and during infection of epithelial cells but are largely down-regulated during infection of macrophage like cells. ${ }^{33,34}$ In contrast, Jones et al. ${ }^{35}$ have reported that in chicken $S$. Typhimurium SPI-1 system is involved in both systemic infection and gut colonization, but does not appear completely crucial for either infection $\mathrm{pr}^{\circ} \mathrm{Cess}$, and in one day old chicks SPI-1 TTSS is not important in the initial stages of infection. ${ }^{35}$ However, in $S$. Pullorum SPI-1 contributes to disease in poultry during infection. ${ }^{36}$ In chickens the majority of $S$. Typhimurium genes involved in flagella production including $f g M, f g N, f g K, f l g B, f l C, f j B, f l i A$ are downregulated. ${ }^{17}$ These are highly immunogenic and immuno-modulatory proteins and their down-regulation in the intestine suggests that a vaccine prepared from bacteria harvested from the intestine may, in fact, express lower levels of key immunogens. The altered expression of these antigens; play a key functional role in establishing infection. ${ }^{37-39}$ It is been reported that flagella play a role in the pathogenesis in chickens ${ }^{40,41}$ and mouse. ${ }^{42,43}$ The result of this study is in agreement with previous work conducted by Toyota-Hanatani et al. ${ }^{44}$ suggesting that a part polypeptide in S. Enteritidis Fli-C (SEp 9) inhibits $S$. Enteritidis colonization in the intestine of chickens two weeks after challenge, similarly to commercial inactivated $S$. Enteritidis vaccine, ${ }^{44}$ S. Enteritidis colonization inhibition by SEp 9 alone may have been comparable to that by commercial inactivated $S$. Enteritidis vaccine.

In S. Typhimurium the SPI-2 TTSS plays a role in both intestinal colonisation and systemic infection of chickens. ${ }^{35}$ Furthermore, microarray work conducted within our group demonstrated that genes of S. Enteritidis Pathogenicity Island (SPI-1, SPI-2 and SPI-5) are up-regulated in vivo indicating a close ass ${ }^{\circ} \mathrm{Ciation}$ with the mucosa during colonization. ${ }^{32}$ It is thus likely that the antigenic profile of Salmonella during the infection of antigen-presenting cells is very different from that of Salmonellae during intestinal colonisation, or that the proteins may have some immune-suppressive effects. ${ }^{45}$ The immunogenicity of bacteria harvested from macrophage infections has not been assessed but given that the biology of Salmonella organisms is very different in the gut and in macrophages, ${ }^{17,32,33}$ as candidate antigen presenting cells, this would be a worthwhile experiment to do. This may suggest that growth of bacteria in the gut to generate a more rational inactivated vaccine may be less important than culturing them in the conditions found within an antigen presenting cell.

As we ensured that the protein concentrations in the vaccine preparations prepared from the in vivo and in vitro cultures were similar and obtained from a similar number of bacteria and we can state that the in vitro bacteria did not produce larger amounts of 
protein compared to the in vivo bacteria. So, the difference may lie in the levels of specific proteins expressed under the different conditions of culture. Thus, in contrast to expectations, in vivo harvested proteins were poorer immunogens than proteins harvested from Salmonellae grown in nutrient broth but were better than killedbacterins.

Formalin killed bacteria as vaccines were therefore found to be poorly protective against faecal shedding. This may be as a result of Salmonella antigen damage during formalization or as a consequence of enzymatic degradation of Salmonella in vivo proteins by avian proteases as found in this study. However, the in vitrocultured formalin-killed bacteria had a slightly better effect than the in vivo bacteria but this was statically not significant. However, formalin killed Salmonella bacterins are used commercially in the field to control the losses acquired by Salmonella in calve in many countries. ${ }^{46,47}$

The caeca empty and fill several times a day and therefore, the phases of growth of the in ${ }^{\circ}$ Culated bacteria in individual birds may be different and a considerable proportion of the cells may be in the stationary phase. In addition, the fall in temperature during the specific experiment before challenge might explain the poor immunity provided for groups treated with this vaccine. Inactivated vaccines can reduce $S$. Enteritidis faecal excretion and that effect may depend on their composition. ${ }^{48}$ Other authors have suggested that several factors may account for this effect, such as adjuvant type and composition, S. Enteritidis strain and inactivation method. ${ }^{49,50}$

In this study (experiment II), when birds were challenged intravenously (systemic infection), to asses Salmonella systemic invasion of internal organs such as spleen and liver, no bacteria were observed in the caecal swabs collected from all birds. This observation is different from what has been reported previously where $S$. Enteritidis was shed in faeces after intravenous challenge. ${ }^{24,51,52}$ The clearance of the challenge strain from internal organs in both vaccinated and unvaccinated birds were similar. During systemic infection following intravenous challenge the macrophage interaction with Salmonellae is the key in the progress of the systemic infection..$^{53}$ Salmonella clearance into gastrointestinal tract from the tissues is through gall bladder. ${ }^{24}$ It is been previously reported that in chickens biliary antibodies are involved in S. Typhimurium clearance from the gut. ${ }^{54}$ This observation correlated with the results of Woodward et al. ${ }^{54}$ who reported that the Salmonella count in gall bladder is higher in unimmunised group compared with vaccinated birds. ${ }^{55}$ However, other authors used a similar route of challenge and reported that bacterial shedding in the faces reached the highest number 1 - 2 weeks post infection, ${ }^{52}$ which might explain the absence of Salmonella from the caecal sample at day 8 .

In the present study a combination of inactivated vaccines and CE was used, with all groups of birds in oCulated with Avigard microflora product prior to exposure to the corresponding vaccine. Such a combination might be considered as a control measure to control infection by Salmonella. Experimentally, a combination of live and CE products was shown to provide a considerable degree of protection of chickens against $S$. Typhimurium. ${ }^{56}$

Protection of the chicken can oCcur from transfer of passive immunity to broiler and layers, so a killed vaccine might be useful and used under these circumstances. However, secretory IgA responses which are thought to play a central role in mucosal surface protection cannot be elicited by killed Salmonellae vaccine..$^{57,58}$

Poultry immunisation against Salmonellae is considered as an important contributory measure to infection control. In chickens vaccination may reduce the severity and period of infection and help avoid re-infection, ${ }^{59}$ which indirectly should reduce the number of human food-borne salmonellosis cases. ${ }^{60}$ It has been shown that inactivated vaccines of $S$. Enteritidis can induce a good humoral immune response, and induce some reduction in intestinal colonization by $S$. Enteritidis. ${ }^{57,61-63}$

Previous studies indicated that humoral responses are less important than cell-mediated immunity in protection against Salmonellae. ${ }^{64,65}$ Other published research agreed that cell mediated immunity determines the overall defense against systemic salmonellosis ${ }^{64,66}$ probably even in the intestine. ${ }^{67}$ Several studies have reported that live vaccines are more effective and provide greater protection than killed vaccines in protecting birds from $S$. Enteritidis infection. ${ }^{61,68-70}$ Much earlier work indicated that compared with a live vaccine killed bacteria do not induce as strong a protective response in controlling fowl typhoid, ${ }^{71}$ and also disease-free intestinal carriage of Salmonella ${ }^{19,20}$ as indicated previously.

It is not clear if one of the reasons is antigen destruction during vaccine preparation or whether in a related way persistent presentation of the antigen on active multiplying bacterial cells is necessary for stimulation. Other researchers have tested $S$. Enteritidis inactivated vaccines (Bacterin with Modified Freund's adjuvant) and demonstrated a variable reduction in the $S$. Enteritidis faecal shedding; the best protection was obtained by bacterins with modified Freund's adjuvant, with the $S$. Enteritidis cells inactivated by $20 \%$ acetone..$^{50}$ An inactivated $S$. Enteritidis PT4 which comprised $10^{11} \mathrm{cfu} / \mathrm{ml}$ in $50 \%$ oil adjuvant was also developed by Timms et al. ${ }^{24}$ which provided a significant protection against both intramuscular and intravenous challenge 5 and 8 weeks post challenge when it inoculated intramuscularly ${ }^{24}$ although it must be remembered that this was parenteral challenge with a bias towards the vaccine. One other reason for reduced immunogenicity of killed Salmonella vaccines is that the presented antigens are expressed under the conditions of culture which in most cases is a rich medium in vitro. ${ }^{72}$ Conversely, live attenuated vaccines may be antibiotic resistant and may be unsafe due to insufficient attenuation. ${ }^{73,74}$ The most extensive currently used inactivated vaccine is produced by culturing Salmonella bacteria under conditions of iron restriction, on the basis that this will generate immunogenic surface proteins required for iron uptake..$^{52}$ However, other factors besides iron restriction are important during infection of macrophages, ${ }^{33}$ or of the intestine. ${ }^{32,75}$ Killed vaccines stimulate antibody production and express only the antigens present at the time of in vitro harvesting. ${ }^{64,72}$ Killed vaccines may be eliminated and destroyed rapidly, with poor immunogenicity in unprimed hosts. ${ }^{63,76}$ In contrast to crude undefined preparations perhaps the future route is through specified proteins known to be immunogenic such as the outer membrane proteins (OMP). Besides lipids and lip polysaccharides the outer membrane of Gram negative bacteria contain some proteins which represent integral proteins of the bacterial outer membrane. ${ }^{77}$ Salmonella OMP play a vital role in the stimulation ofimmune response and may be used as effective vaccine candidates providing active immunity. A previous study used $S$. Enteritidis isolated from chicken meat showed that OMPs of molecular weight 14.4 - $24 \mathrm{KDa}$ are immunogenic and might be used for vaccine preparation to control salmonellosis in human and animals. ${ }^{77}$ Another study revealed that $S$. Typhimurium strains contain OMPs of 37 and 40 and $41.7 \mathrm{KDa}^{78}$ S. Enteritidis OMPs are effective in reducing colonization of $S$. Enteritidis on intestinal mucosa in chickens and could be used as potential vaccines to reduce $S$. Enteritidis colonization in chickens. ${ }^{6}$ (Adjuvanted OMP vaccines gave better protection than sonicated extract of $S$. Enteritidis vaccines. ${ }^{79}$ 
Although Salmonella bacterins may not be effective against intestinal colonization, albeit moderately against invasion of chicken visceral organs,$^{80}$ better protection can be obtained in laying hens when a combination of both live $S$. Enteritidis, followed by a bacteria is used. ${ }^{81}$ In poultry vaccines against Salmonella infection are thus incompletely effective, and must be seen as a single component in Salmonella control regimens involving a combination of vaccination programs together with hygienic measures.

\section{Conflicts of Interest}

The authors declare no conflict of interest.

\section{Acknowledgments}

None.

\section{Funding}

None.

\section{References}

1. Thorns CJ, Turcotte C, Gemmell CG, et al. Studies into the role of the SEF14 fimbrial antigen in the pathogenesis of Salmonella enteritidis. Microb Pathog. 1996;20(4):235-246.

2. Barrow PA, Simpson JM, Lovell MA. Intestinal colonisation in the chicken by food-poisoning Salmonella serotypes; microbial characteristics ass $^{\circ}$ Ciated with faecal excretion. Avian Pathol. 1988;17(3):571-588.

3. Morgan E, Campbell JD, Rowe SC, et al. Identification of host-specific colonization factors of Salmonella enterica serovar Typhimurium. Mol Microbiol. 2004;54(4):994-1010.

4. Craven SE, Cox NA, Bailey JS, et al. Characterization of Salmonella california and S. typhimurium strains with reduced ability to colonize the intestinal tract of broiler chicks. Avian diseases. 1993;37(2):339348.

5. Turner AK, Lovell MA, Hulme SD, et al. Identification of Salmonella typhimurium genes required for colonization of the chicken alimentary tract and for virulence in newly hatched chicks. Infect Immun. 1998;66(5):2099-2106.

6. Khan MI, Fadl AA, Venkitanarayanan KS. Reducing colonization of Salmonella Enteritidis in chicken by targeting outer membrane proteins. J Appl Microbiol. 2003;95(1):142-145.

7. Smith HW, Tucker JF. The effect of feeding diets containing permitted antibiotics on the faecal excretion of Salmonella typhimurium by experimentally infected chickens. J Hyg. 1975;75(2):293-301.

8. Smith HW. The development of the flora of the alimentary tract in young animals. J Pathol Bacteriol. 1965;90(2):495-513.

9. Miles AA, Misra SS. The estimation of the bactericidal power of blood. J Hyg (Lond). 1938;38(6):732-749.

10. Dibb Fuller MP, Allen Vercoe E, Thorns CJ, et al. Fimbriae-and flagellamediated ass ${ }^{\circ}$ Ciation with and invasion of cultured epithelial cells by Salmonella enteritidis. Microbiology. 1999;145(Pt 5):1023-1031.

11. Cooper GL, Venables LM, Nicholas RA, et al. Vaccination of chickens with chicken-derived Salmonella enteritidis phage type 4 aroA live oral Salmonella vaccines. Vaccine. 1992;10(4):247-254.

12. Smith HW. Observations on the Flora of the Alimentary Tract of Animals and Factors Affecting Its Composition. $J$ Pathol Bacteriol. 1965;89:95-122.

13. Woodall CA, Jones MA, Barrow PA, et al. Campylobacter jejuni gene expression in the chick cecum: evidence for adaptation to a low-oxygen environment. Infect Immun. 2005;73(8):5278-5285.
14. Barrow PA, Simpson JM, Kirk SJ, et al. The effect of halofuginone on the excretion of Salmonella typhimurium by experimentally infected chickens. Vet Microbiol. 1988;17(1):59-64.

15. Jones SA, Chowdhury FZ, Fabich AJ, et al. Respiration of Escherichia coli in the mouse intestine. Infection and immunity. 2007;75(10):48914899.

16. Jones SA, Jorgensen M, Chowdhury FZ, et al. Glycogen and maltose utilization by Escherichia coli O157:H7 in the mouse intestine. Infect Immun. 2008;76(6):2531-2540.

17. Harvey PC, Watson M, Hulme S, et al. Salmonella enterica serovar typhimurium colonizing the lumen of the chicken intestine grows slowly and upregulates a unique set of virulence and metabolism genes. Infect Immun. 2011;79(10):4105-4121.

18. Smith HW, Tucker JF. The effect of antibiotic therapy on the faecal excretion of Salmonella typhimurium by experimentally infected chickens. J Hyg (Lond). 1975;75(2):275-292.

19. Bisping W, Dimitriadis I, Seippel M. [Studies on oral immunization of chickens with heat inactivated salmonella vaccine. 1. Studies on vaccination and infection of chicks]. Zentralbl Veterinarmed $B$. 1971;18(4):306-311.

20. Thain JA, Baxter Jones C, Wilding GP, et al. Serological response of turkey hens to vaccination with Salmonella hadar and its effect on their subsequently challenged embryos and poults. Res Vet Sci. 1984;36(3):320-325.

21. Meyer $\mathrm{H}, \mathrm{K}^{\circ} \mathrm{Ch} \mathrm{H}$, Methner $\mathrm{U}$, et al. Vaccines in salmonellosis control in animals. Zentralbl Bakteriol. 1993;278(2-3):407-415.

22. Barnes EM. The avian intestinal flora with particular reference to the possible ecological significance of the cecal anaerobic bacteria. Am J Clin Nutr. 1972;25(12):1475-1479.

23. Williams JE, Whittemore AD. Field applications of MA and MAG tests for detection of avian salmonellosis. $\mathrm{Pr}^{\circ} \mathrm{C}$ Annu Meet U S Anim Health Ass ${ }^{\circ}$ C. 1976;(80):297-303

24. Timms LM, Marshall RN, Breslin MF. Laboratory assessment of protection given by an experimental Salmonella enteritidis PT4 inactivated, adjuvant vaccine. Vet Rec. 1990;127(25-26):611-614.

25. Bouzoubaa K, Nagaraja KV, Newman JA, et al. Use of membrane proteins from Salmonella gallinarum for prevention of fowl typhoid infection in chickens. Avian Dis. 1987;31(4):699-704.

26. Pati US, Srivastava SK, Roy SC, et al. Immunogenicity of outer membrane protein of Pasteurella mult ${ }^{\circ} \mathrm{Cida}$ in buffalo calves. Vet Microbiol. 1996;52(3-4): 301-311.

27. Kleanthous H, Lee CK, Monath TP. Vaccine development against infection with Helicobacter pylori. Br Med Bull. 1998;54(1):229-241.

28. Marchetti M, Rossi M, Giannelli V, et al. Protection against Helicobacter pylori infection in mice by intragastric vaccination with $\mathrm{H}$. pylori antigens is achieved using a non-toxic mutant of E. coli heat-labile enterotoxin (LT) as adjuvant. Vaccine. 1998;16(1):33-37.

29. Lee J, Cao L, Ow SY, et al. Proteome changes after metabolic engineering to enhance aerobic mineralization of cis-1,2-dichloroethylene. $J$ Proteome Res. 2006;5(6):1388-1397.

30. Radcliff FJ, Hazell SL, Kolesnikow T, et al. Catalase, a novel antigen for Helicobacter pylori vaccination. Infect Immun. 1997;65(11):4668-4674.

31. Kuusi N, Nurminen M, Saxen H, et al. Immunization with major outer membrane proteins in experimental salmonellosis of mice. Infect Immun. 1979;25(3):857-862.

32. Dhawi AA, Elazomi A, Jones MA, et al. Adaptation to the chicken intestine in Salmonella Enteritidis PT4 studied by transcriptional analysis. Vet Microbiol. 2011;153(1-2):198-204. 
33. Eriksson S, Lucchini S, Thompson A, et al. Unravelling the biology of macrophage infection by gene expression profiling of intracellular Salmonella enterica. Mol Microbiol. 2003;47(1):103-118.

34. Hautefort I, Thompson A, Eriksson Ygberg S, et al. During infection of epithelial cells Salmonella enterica serovar Typhimurium undergoes a time-dependent transcriptional adaptation that results in simultaneous expression of three type 3 secretion systems. Cell Microbiol. 2008;10(4):958-984.

35. Jones MA, Hulme SD, Barrow PA, et al. The Salmonella pathogenicity island 1 and Salmonella pathogenicity island 2 type III secretion systems play a major role in pathogenesis of systemic disease and gastrointestinal tract colonization of Salmonella enterica serovar Typhimurium in the chicken. Avian Pathol. 2007;36(3):199-203.

36. Wigley P, Jones MA, Barrow PA. Salmonella enterica serovar Pullorum requires the Salmonella pathogenicity island 2 type III secretion system for virulence and carriage in the chicken. Avian Pathol. 2002;31(5):501506.

37. Ikeda JS, Schmitt CK, Darnell SC, et al. Flagellar phase variation of Salmonella enterica serovar Typhimurium contributes to virulence in the murine typhoid infection model but does not influence Salmonellainduced enteropathogenesis. Infection and immunity. 2001;69(5):30213030 .

38. Schmitt CK, Ikeda JS, Darnell SC, et al. Absence of all components of the flagellar export and synthesis machinery differentially alters virulence of Salmonella enterica serovar Typhimurium in models of typhoid fever, survival in macrophages, tissue culture invasiveness, and calf enter ${ }^{\circ}$ Colitis. Infect Immun. 2001;69(9):5619-5625.

39. Robertson JM, McKenzie NH, Duncan M, et al. Lack of flagella disadvantages Salmonella enterica serovar Enteritidis during the early stages of infection in the rat. J Med Microbiol. 2003;52(Pt 1):91-99.

40. Oyofo BA, Droleskey RE, Norman JO, et al. Inhibition by mannose of in vitro colonization of chicken small intestine by Salmonella typhimurium. Poultry science. 1989;68(10):1351-1356.

41. Lee MD, Curtiss R, Peay T. The effect of bacterial surface structures on the pathogenesis of Salmonella typhimurium infection in chickens. Avian diseases. 1996;40(1):28-36.

42. L $^{\circ} \mathrm{Ckman}$ HA, Curtiss R (1990) Salmonella typhimurium mutants lacking flagella or motility remain virulent in BALB/c mice. Infection and immunity. 1990;58(1):137-143.

43. $\mathrm{L}^{\circ} \mathrm{Ckman} \mathrm{HA}$, Curtiss R, $3^{\text {rd }}$. Virulence of non-type 1-fimbriated and nonfimbriated nonflagellated Salmonella typhimurium mutants in murine typhoid fever. Infection and immunity. 1992;60(2):491-496.

44. Toyota HY, Kyoumoto Y, Baba E, et al. Importance of subunit vaccine antigen of major Fli $\mathrm{C}$ antigenic site of Salmonella enteritidis II: a challenge trial. Vaccine. 2009;27(11):1680-1684.

45. Pavlova B, Volf J, Ondrackova P, et al. SPI-1-encoded type III secretion system of Salmonella enterica is required for the suppression of porcine alveolar macrophage cytokine expression. Vet Res. 2011;42(1):16.

46. Wray C, Sojka WJ. The serological responses of calves to live Salmonella dublin vaccine - a comparison of different serological tests. J Biol Stand. 1984;12(3):277-282.

47. Da Roden L, Smith BP, Spier SJ, et al. Effect of calf age and Salmonella bacterin type on ability to produce immunoglobulins directed against Salmonella whole cells or lipopolysaccharide. Am J Vet Res. 1992;53(10):1895-1899.

48. Liu W, Yang Y, Chung N, et al. Induction of humoral immune response and protective immunity in chickens against Salmonella enteritidis after a single dose of killed bacterium-loaded microspheres. Avian diseases. 2001;45(4):797-806.

49. Freitas ${ }^{\circ} \mathrm{C}$, Mesquita AL, Paiva JB, et al. Control of Salmonella enterica serovar Enteritidis in laying hens by inactivated Salmonella Enteritidis vaccine. Brazilian Journal of Microbiology. 2008;39(2):390-396.
50. Barbour EK, Frerichs WM, Nabbut NH, et al. Evaluation of bacterins containing three predominant phage types of Salmonella enteritidis for prevention of infection in egg-laying chickens. Am J Vet Res. 1993;54(8):1306-1309.

51. Gast RK, Stone HD, Holt PS, et al. Evaluation of the efficacy of an oilemulsion bacterin for protecting chickens against Salmonella enteritidis. Avian Dis. 1992;36(4):992-999.

52. Clifton Hadley FA, Breslin M, Venables LM, et al. (2002) A laboratory study of an inactivated bivalent iron restricted Salmonella enterica serovars Enteritidis and Typhimurium dual vaccine against Typhimurium challenge in chickens. Veterinary microbiology. 2002;89(2-3):167-179.

53. Barrow PA, Huggins MB, Lovell MA, et al. Host specificity of Salmonella infection in chickens and mice is expressed in vivo primarily at the level of the reticuloendothelial system. Infect Immun. 1994;62(10):4602-4610.

54. Lee GM, Jackson GD, Cooper GN. The role of serum and biliary antibodies and cell-mediated immunity in the clearance of S-typhimurium from chickens. Vet Immunol Immunopathol. 1981;2(3):233-252.

55. Woodward MJ, Gettinby G, Breslin MF, et al. The efficacy of Salenvac, a Salmonella enterica subsp. Enterica serotype Enteritidis iron-restricted bacterin vaccine, in laying chickens. Avian Pathol. 2002;31(4):383-392.

56. Methner U, Barrow PA, Berndt A, et al. Combination of vaccination and competitive exclusion to prevent Salmonella colonization in chickens: experimental studies. International journal of food microbiology. 1999;49(1-2):35-42.

57. Desmidt M, Ducatelle R, Mast J, et al. Role of the humoral immune system in Salmonella enteritidis phage type four infection in chickens. Vet Immunol Immunopathol. 1998;63(4):355-367.

58. Barrow PA, Berchieri A, al Haddad O. Serological response of chickens to infection with Salmonella gallinarum-S. pullorum detected by enzyme-linked immunosorbent assay. Avian Dis. 1992;36(2):227-236.

59. Gast RK. Serotype-specific and serotype-independent strategies for preharvest control of food-borne Salmonella in poultry. Avian. 2007;51(4):817-828.

60. Collard JM, Bertrand S, Dierick K, et al. Drastic decrease of Salmonella Enteritidis isolated from humans in Belgium in 2005, shift in phage types and influence on foodborne outbreaks. Epidemiol Infect. 2008;136(6):771-781.

61. Babu U, Dalloul RA, Okamura M, et al. Salmonella enteritidis clearance and immune responses in chickens following Salmonella vaccination and challenge. Vet Immunol Immunopathol. 2004;101(3-4):251-257.

62. Hassan JO, Curtiss R. Control of colonization by virulent Salmonella typhimurium by oral immunization of chickens with avirulent delta cya delta crp S. typhimurium. Research in microbiology. 1990;141(78):839-850.

63. Nagaraja, Rajashekara. Vaccination against Salmonella enterica serovar Enteritidis infection:dilemma and realities. In: Saeed AM \& Richard K Gast (Eds.) Salmonella enterica serovar Enteritidis in humans and animals Ames, Iowa State University Press, USA, 1999; pp. 397-404.

64. Collins FM. Vaccines and cell-mediated immunity. Bacteriol Rev. 1974;38(4):371-402.

65. Mastroeni P, Villarreal Ramos B, Hormaeche CE. Adoptive transfer of immunity to oral challenge with virulent salmonellae in innately susceptible BALB/c mice requires both immune serum and $\mathrm{T}$ cells. Infect Immun. 1993;61(9):3981-3984.

66. Cameron CM, Brett OL, Fuls WJ, et al. The effect of immunosuppression on the development of immunity to fowl typhoid. Onderstepoort $J$ Vet Res. 1974;41(1):15-21.

67. Beal RK, Powers C, Davison TF, et al. Clearance of enteric Salmonella enterica serovar Typhimurium in chickens is independent of B-cell function. Infection and immunity. 2006;74(2):1442-1444. 
68. Betancor L, Schelotto F, Fernandez M, et al. An attenuated Salmonella Enteritidis strain derivative of the main genotype circulating in Uruguay is an effective vaccine for chickens. Vet Microbiol. 2005;107(1-2):8189.

69. Martin G, Barrow PA, Berchieri A, et al. [Inhibition phenomena between Salmonella strains - a new aspect of salmonella infection control in poultry]. Dtsch Tierarztl W'Chenschr. 1996;103(11):468-472.

70. Kirkpatrick BD, McKenzie R, O Neill JP, et al. Evaluation of Salmonella enterica serovar Typhi (Ty2 $\operatorname{ar}^{\circ} \mathrm{C}-\mathrm{SsaV}-$ ) M01ZH09, with a defined mutation in the Salmonella pathogenicity island 2, as a live, oral typhoid vaccine in human volunteers. Vaccine. 2006;24(2):116-123.

71. Smith HW. The use of live vaccines in experimental Salmonella gallinarum infection in chickens with observations on their interference effect. The Journal of hygiene. 1956;54(3):419-432.

72. Barrow PA, Wallis TS (2000) Vaccination against Salmonella infections in food animals: rationale, theoretical basis and practical application. In: Wray A \& wray C, Editors. Salmonella in domestic animals. CAB International, Oxford, England, UK, 2000; p. 455.

73. Arnon R, Shapira M, Jacob CO. Synthetic vaccines. J Immunol Methods. 1983;61(3):261-273.

74. Barrow PA, Page K, Lovell MA. The virulence for gnotobiotic pigs of live attenuated vaccine strains of Salmonella enterica serovars Typhimurium and Enteritidis. Vaccine. 2001;19(25-26):3432-3436.
75. Nielsen AT, Dolganov NA, Rasmussen T, et al. (2010) A bistable switch and anatomical site control Vibrio cholerae virulence gene expression in the intestine. PLoS Pathog. 2010;6(9):e1001102.

76. Barrow PA, Lovell MA. Experimental infection of egg-laying hens with Salmonella enteritidis phage type 4. Avian Pathol. 1991;20(2):335-348.

77. Maripandi A, Al Salamah AA. Analysis of Salmonella enteritidis Outer Membrane Proteins and Lipopolysaccharide Profiles with the Detection of Immune Dominant Proteins. American Journal of Immunology. 2010;6(1):1-6.

78. Helmuth R, Stephan R, Bunge C, et al. Epidemiology of virulenceass ${ }^{\circ}$ Ciated plasmids and outer membrane protein patterns within seven common Salmonella serotypes. Infection and immunity. 1985;48(1):175-182.

79. Meenakshi M, Bakshi CS, Butchaiah G, et al. Adjuvanted outer membrane protein vaccine protects poultry against infection with Salmonella enteritidis. Vet Res Commun. 1999;23(2):81-90.

80. Nakamura M, Nagamine N, Takahashi T, et al. Evaluation of the efficacy of a bacterin against Salmonella enteritidis infection and the effect of stress after vaccination. Avian Dis. 1994;38(4):717-724.

81. Nassar TJ, al Nakhli HM, al Ogaily ZH. Use of live and inactivated Salmonella enteritidis phage type 4 vaccines to immunise laying hens against experimental infection. Rev Sci Tech. 1994;13(3):855-867. 